\title{
Changes during the menstrual cycle in cytosolic and nuclear concentrations of progestagen receptor in the human Fallopian tube
}

\author{
A. M. Pino, L. Devoto*†, M. Dávila and E. Soto* \\ División de Ciencias Básicas, INTA, Universidad de Chile, Casilla 15138, Santiago 11, \\ * Departamento de Obstetricia y Ginecología, Universidad de Chile, SNS, and †Instituto de \\ Investigaciones Clínicas, Hospital Paula Jaraquemada, Casilla 5370, Santiago 3, Chile
}

\begin{abstract}
Summary. $\left[{ }^{3} \mathrm{H}\right] \mathrm{R} 5020$ was bound to cytosolic and nuclear samples of human Fallopian tube with high affinity and specificity. The cytoplasmic and nuclear concentrations of progestagen receptor varied, throughout the menstrual cycle, in the ampulla, isthmus and fimbria. Concentrations were higher at the late proliferative stage of the cycle than at the early proliferative and late secretory stages. A positive linear regression was observed between cytosolic and nuclear progestagen receptor concentrations and plasma oestradiol levels. A negative linear relationship was observed between cytosolic progestagen receptor concentration and plasma progesterone levels during the secretory stages of the menstrual cycle.
\end{abstract}

\section{Introduction}

In human Fallopian tube, as well as in animal oviducts, oestradiol is necessary to induce and maintain a mature epithelium with ciliated and secretory cells. The surge of progesterone after ovulation causes deciliation and loss of secretory activity in the epithelial cells (Brenner, Resko \& West, 1974; Verhage, Bareither, Jaffe \& Akbar, 1979).

The concentrations of oestradiol and progesterone receptors in a particular cell are partly regulated by the plasma levels of oestradiol and progesterone (Little, Szendro, Terán, Hughes \& Jungblut, 1975; Leavitt, Chen \& Allen, 1977), which change according to the ovarian cycle.

We have examined the variations in content of cytosolic and nuclear progestagen receptors during the menstrual cycle.

\section{Materials and Methods}

Tissues. Fallopian tubes from normally menstruating patients were obtained after surgical sterilization or total hysterectomy (bilateral salpingo-oophorectomy because of cervical intraepithelial neoplasm). All samples were obtained after signed informed consent.

\section{Determination of the stages of the menstrual cycle}

Plasma oestradiol and progesterone concentrations were determined by radioimmunoassays as previously reported (Devoto, Soto, Magofke \& Sierralta, 1980). 
The endocrine profile was corroborated by a careful morphological description of the ovary at the time of laparotomy and by dating the endometrial biopsy (Noyes, Hertig \& Rock, 1950). The stages of the cycle were identified as (1) early proliferative (before the start of the oestradiol peak), (2) late proliferative (plasma oestradiol concentration $>200 \mathrm{pg} / \mathrm{ml}$ ), (3) early secretory (24-96 h after the LH peak), (4) late secretory ( $>96 \mathrm{~h}$ after the LH peak). The side of the Fallopian tube in relation to the ripe follicle or corpus luteum was noted.

\section{Tissue preparation}

The Fallopian tube was trimmed free of fat, connective tissue and peritoneum and placed in icecold Buffer A (10 mM-phosphate buffer, pH 7.4, containing $250 \mathrm{~mm}$-sucrose, $5 \mathrm{~mm}$-sodium azide, $10 \mathrm{~mm}$-dithiothreitol, $1.5 \mathrm{~mm}$-EDTA and $20 \%(\mathrm{v} / \mathrm{v})$ glycerol $)$. The tube was divided into its isthmic, ampullary and fimbrial parts and each one was rinsed, weighed, minced and homogenized in 5 volumes of Buffer A, as previously reported (Sierralta, Pino, Magofke, Soto \& Devoto, 1981).

Tissue homogenates were filtered through fine gauze and centrifuged at $800 \mathrm{~g}$ for $10 \mathrm{~min}$. To prepare the crude nuclear suspension, the pellet was washed twice with 5 volumes of Buffer $\mathrm{A}$, centrifuged at $800 \mathrm{~g}$ for $10 \mathrm{~min}$ and resuspended in $1.2 \mathrm{ml}$ Buffer B (10 mM-phosphate buffer, pH 7.4, containing $5 \mathrm{~mm}$-sodium azide, $10 \mathrm{~mm}$-DTT, $1.5 \mathrm{~mm}$-EDTA and $20 \%$ (v/v) glycerol).

Pooled $800 \mathrm{~g}$ supernatants were centrifuged at $100000 \mathrm{~g}$ for $60 \mathrm{~min}$ at $4^{\circ} \mathrm{C}$. The supernatant thus obtained was designated as cytosol.

\section{Progesterone binding measurements}

Cytosol binding. Cytosol $(225 \mu \mathrm{l})$ was incubated with a solution of $17 \alpha-$ methyl- $\left[{ }^{3} \mathrm{H}\right] \mathrm{R} 5020$ (sp. act. $87 \mathrm{Ci} / \mathrm{mmol}$ : New England Nuclear Corp., Boston, MA, U.S.A.) in Buffer A to give a final concentration of $16 \times 10^{-9} \mathrm{M}$. Corrections for non-specific binding were made by subtracting the amount of $\left[{ }^{3} \mathrm{H}\right] \mathrm{R} 5020$ bound in the presence of a 200-fold excess of unlabelled R5020 (New England Nuclear).

The $K_{\mathrm{d}}$ and number of binding sites were calculated from Scatchard plots (Scatchard, 1949) using the correction of Rosenthal (1967) and analysing at least 8 binding points for each sample. In these studies the final concentrations of $\left[{ }^{3} \mathrm{H}\right] \mathrm{R} 5020$ in the incubation mixtures ranged from $1 \times 10^{-10}$ to $20 \times 10^{-9} \mathrm{M}$.

All cytosol incubations were at $25^{\circ} \mathrm{C}$ for $30 \mathrm{~min}$, followed by an additional period of $30 \mathrm{~min}$ at $0^{\circ} \mathrm{C}$. Bound progestagen was determined by the charcoal adsorption procedure of Sanborn, Rao \& Korenman (1971).

Nuclear binding. The crude nuclear suspension was incubated overnight at $0-4^{\circ} \mathrm{C}$ with $\left[{ }^{3} \mathrm{H}\right] \mathrm{R} 5020$ as described for cytosol. Bound progestagen was determined by hydroxylapatite adsorption as described by Walters, Hunziker \& Clark (1980).

\section{General procedures}

Radioactivity was measured in a Nuclear Chicago Mark II liquid scintillation spectrometer, with a ${ }^{3} \mathrm{H}$ efficiency of $40-45 \%$. Protein was determined according to the procedure of Biorad Laboratories (Bradford, 1976). Statistical significance was assessed by Student's $t$ test.

\section{Results}

\section{Assay of cytosol binding}

A high progestagen binding affinity was measured in samples of ampulla cytosol; $K_{\mathrm{d}}$ values of $3.93 \pm 2$ and $1.8 \pm 0.3 \mathrm{nM}$ were obtained for samples from the proliferative and secretory phases, respectively. 
Cytosolic and nuclear progestagen receptor levels during the menstrual cycle

The changes in cytosol receptor levels through the menstrual cycle are shown in Text-fig. 1(a). The receptor content in isthmus and ampulla varied during the stages of the menstrual cycle and was significantly higher $(P<0.02)$ at the late proliferative stage. Fimbrial cytosolic receptor showed a less marked variation through the cycle. A higher content of progestagen receptor was found at all stages of the cycle in ampullary tissue. The content of ampullary cytosolic progestagen receptor was analysed with respect to changes in plasma oestradiol and progesterone concentrations. A positive linear correlation $(r=0.833)$ was found between progestagen receptor and plasma oestradiol during the proliferative phases of the cycle (Text-fig. 2a). However, when all 4 stages of the cycle were considered, a lower regression coefficient was obtained $(r=0 \cdot 66)$. Plasma progesterone concentration correlated negatively $(r=-0.738)$ with cytosol progestagen receptor only during the secretory phase (Text-fig. 2 b).

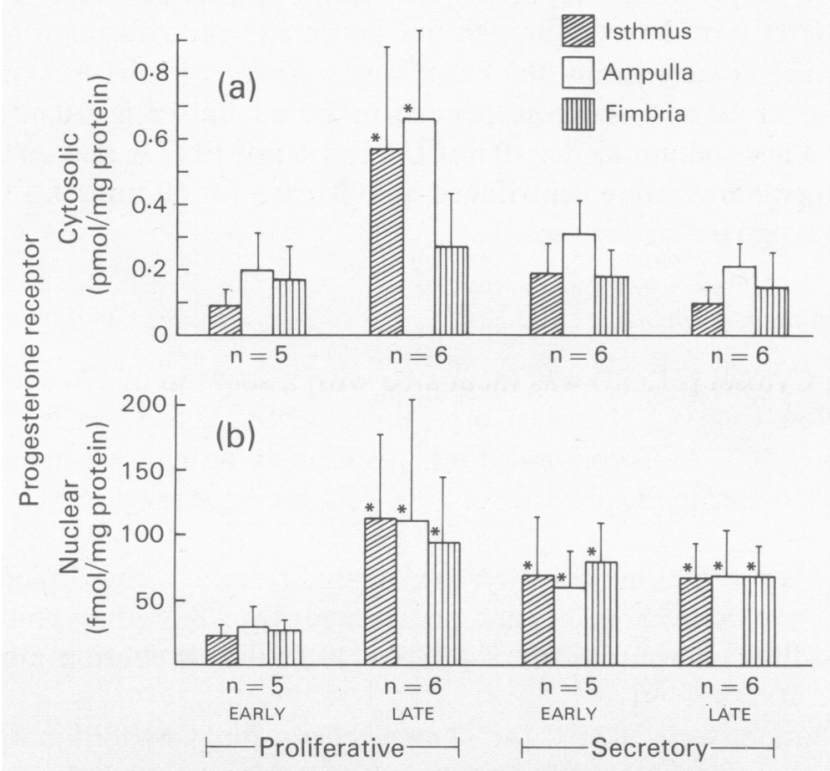

Text-fig. 1. Cytosolic (a) and nuclear (b) progestagen receptor concentrations in the human oviduct during the menstrual cycle. Values are mean \pm s.d. for the no. of samples indicated. *Value significantly higher $(\mathrm{a}, P<0.02 ; \mathrm{b}, P<0.05)$ than the corresponding concentration at the early proliferative stage.
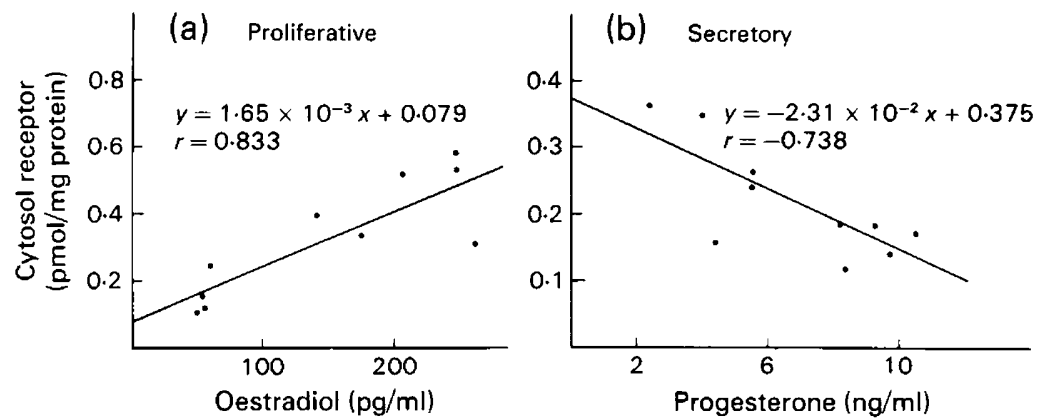

Text-fig. 2. Correlation between ampullary cytosolic progestagen receptor concentration and plasma concentrations of (a) oestradiol and (b) progesterone in women. 
Progestagen nuclear receptor variations during the cycle are shown in Text-fig. 1(b). Values were low in all segments at the early proliferative stage, but a marked increase in receptor content was observed for late proliferative stage and secretory phase samples. There were no significant differences in receptor content amongst the three anatomical segments during the cycle. No correlation was found between nuclear progestagen receptor content and plasma progesterone concentration $(r=0 \cdot 02)$. However, a linear regression with respect to plasma oestradiol was found $(r=0.719)$ (Text-fig. 3a). This could be a consequence of the effect of oestradiol on cytosolic progestagen receptor content, as indicated by the positive linear regression $(r=0.833)$ between the cytosolic and nuclear receptor contents (Text-fig. 3b).
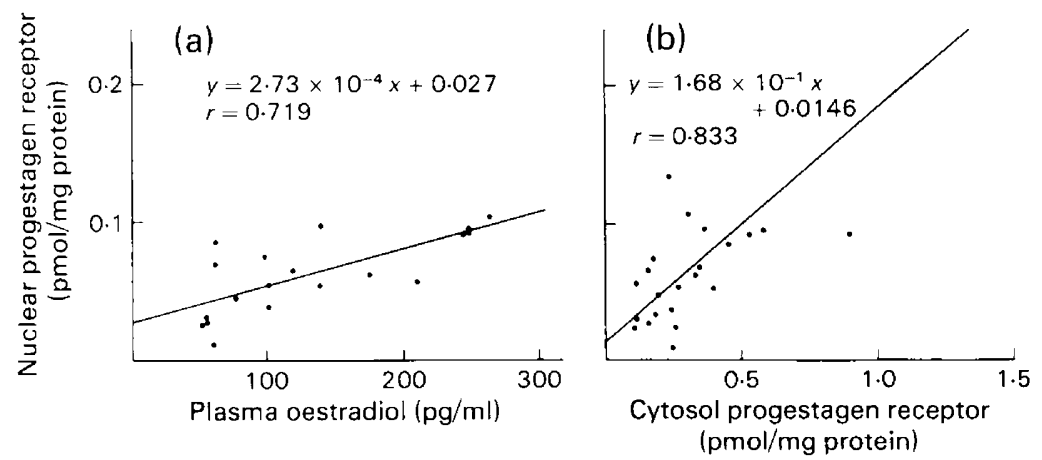

Text-fig. 3. Correlations between nuclear progestagen receptor concentrations and (a) plasma levels of oestradiol, and (b) cytosolic progestagen receptor concentrations in the ampulla of the human oviduct.

\section{Discussion}

The progestagen receptor concentrations measured in the Fallopian tube during the menstrual cycle of women in this study are similar to those reported by Verhage, Akbar \& Jaffe (1980), Punnonen \& Lukola (1981) and Pollow, Inthraphuvasak, Manz, Grill \& Pollow (1981).

The observed variations in the content of oviduct cytosolic and nuclear progestagen receptors throughout the menstrual cycle suggest that the progestagen receptor is under dual hormonal control, as reported to occur in animal and human tissues (Vu Hai, Logeat, Warenbourg \& Milgrom, 1977; Tseng, Gusberg \& Gurpide, 1977).

During the proliferative phase and for the whole cycle, a positive linear regression was found for plasma oestradiol and cytosolic progestagen receptor content, supporting the assumption that oestradiol stimulates the synthesis of cytosolic progestagen receptor in the oviduct (Leavitt et al., 1977).

The positive effect of oestradiol was also shown for the nuclear progestagen receptor content throughout the whole cycle, suggesting that oestradiol priming of the tissue is required to provide enough cytosolic receptor for translocation to the nucleus. The positive linear correlation found between cytosolic and nuclear progestagen receptor concentrations gives indirect support to the above conclusion.

The decrease of cytosolic progestagen receptor during the secretory phase may be explained by (a) translocation of cytosolic receptor to the nucleus (Vu Hai et al., 1977), (b) a negative effect of progesterone on its receptor synthesis (Vu Hai et al., 1977), and (c) a decrease of the stimulatory effect of oestradiol (Evans \& Leavitt, 1980). Events (a) and (b) could account for the negative correlation observed between plasma progesterone and cytosolic progestagen receptor concentrations.

At all phases of the cycle the nuclear progestagen receptor content in the oviduct was (i) only a 
small fraction of the available total cytosolic receptor and (ii) similar in all 3 anatomical segments studied although the cytosolic receptor values were significantly different. Pino, Devoto, Soto, Castro \& Sierralta (1982) reported that more oestradiol receptors were present in human oviducal nuclei than in the cytosol. It would therefore seem that other non-receptor factors are involved in the distribution of progesterone in the Fallopian tube.

The oviducal response to progesterone action can be related to the increased activity of oestradiol-17 dehydrogenase during the secretory phase (Sierralta et al., 1981). In the human endometrium, an increase of this enzyme activity during long-term progesterone domination has been reported (Tseng \& Gurpide, 1974, 1975), leading to the hypothesis that enhanced oxidation of oestradiol constitutes a long-term mechanism for progesterone antagonism of oestradiol action. The increase of oestradiol-17 $\beta$ dehydrogenase followed by an increased content of oestrone (Devoto et al., 1980) during the secretory phase suggests that the same mechanism operates in the oviduct.

We thank Dr José Minguell for advice on the manuscript and Mr J. Merino for technical help. This work was supported by Rockefeller Grant GAPS 8131.

\section{References}

Bradford, M. (1976) Protein assay by dye binding. Analyt. Biochem. 73, 248-253.

Brenner, R.M., Resko, J.A. \& West, N.B. (1974) Cyclic changes in oviductal morphology and residual cytoplasmic estradiol binding capacity induced by sequential estradiol-progesterone treatment of spayed rhesus monkeys. Endocrinology 95, 10941104.

Devoto, L., Soto, E., Magofke, A.M. \& Sierralta, W. (1980) Unconjugated steroids in the Fallopian tube and peripheral blood during the normal menstrual cycle. Fert. Steril. 33, 613-617.

Evans, R.W. \& Leavitt, W.W. (1980) Progesterone inhibition of uterine nuclear estrogen receptor: dependence on RNA and protein synthesis. Proc. Natn. Acad. Sci. U.S.A. 77, 5856-5860.

Leavitt, W., Chen, T.J. \& Allen, T.C. (1977) Regulation of progesterone receptor formation by estrogen action. Ann. N.Y. Acad. Sci. 286, 210-225.

Little M., Szendro, P.I., Terán, C., Hughes, A. \& Jungblut, P.W. (1975) Biosynthesis and transformation of microsomal cytosol estradiol receptors. J. Steroid Biochem. 6, 493-500.

Noyes, R., Hertig, A. \& Rock, J. (1950) Dating the endometrial biopsy. Fert. Steril. 1, 3-8.

Pino, A.M., Devoto, L., Soto, E., Castro, O. \& Sierralta, W. (1982) Changes in cytosolic and nuclear estradiol of normal Fallopian tube throughout the menstrual cycle. J. Steroid Biochem. 16, 193-197.

Pollow, K., Inthraphuvasak, J., Manz, B., Grill, H.J. \& Pollow, B. (1981) A comparison of cytoplasmic and nuclear estradiol and progesterone receptors in human Fallopian tube and endometrial tissue. Fert. Steril. 36, 615-622.

Punnonen, R. \& Lukola, A. (1981) Binding of estrogen and progestin in the human Fallopian tube. Fert. Steril. 36, 610-614.

Rosenthal, H.E. (1967) A graphic method for the determination and presentation of binding parameters in a complex system. Analyt. Biochem. 20, 525532.

Sanborn, B.M., Rao, B.R. \& Korenman, S.C. (1971) Interaction of $17 \beta$-estradiol and its specific receptor. Evidence for complex kinetic and equilibrium behavior. Biochemistry, N.Y. 10, 4955-4960.

Scatchard, G. (1949) The attractions of proteins for small molecules and ions. Ann. N.Y. Acad. Sci. 51, 660-672.

Sierralta, W., Pino, A.M., Magofke, A.M., Soto, E. \& Devoto, L. (1981) Estradiol dehydrogenase activity in the Fallopian tube during the normal menstrual cycle. Arch. Gynäk 230, 189-194.

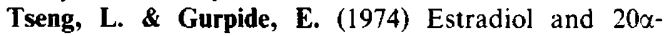
dihydroprogesterone dehydrogenase activity in human endometrium during the menstrual cycle. Endocrinology 94, 419-423.

Tseng, L. \& Gurpide, E. (1975) Induction of human endometrial estradiol dehydrogenase by progestins. Endocrinology 97, 825-833.

Tseng, L., Gusberg, S.B. \& Gurpide, E. (1977) Estradiol receptor and $17 \beta$-dehydrogenase in normal and abnormal endometrium. Ann. N.Y. Acad. Sci. 286, 190-198.

Verhage, H.G., Bareither, M.L., Jaffe, R.C. \& Akbar, M. (1979) Cyclic changes in ciliation, secretion and cell height of the oviductal epithelium in women. $A m . J$. Anat. 156, 505-522.

Verhage, H.G., Akbar, M. \& Jaffe, R.C. (1980) Cyclic changes in cytosol progesterone receptor of human Fallopian tube. J. clin. Endocr. Metab. 51, 776-780.

Vu Hai, M.T., Logeat, F., Warenbourg, M. \& Milgrom, E. (1977) Hormonal control of progesterone receptors. Ann. N.Y. Acad. Sci. 286, 199-209.

Walters, M.R., Hunziker, W. \& Clark, J.H. (1980) Hydroxyapatite prevents nuclear receptor loss during the exchange assay of progesterone receptors. $J$. Steroid Biochem. 13, 1129-1132. 